\title{
IMPLEMENTASI MODEL INTEGER PROGRAMMING DALAM MENGOPTIMALKAN PRODUKSI “KURMA BABE” KOTA KUPANG
}

\author{
V. S. Adoe1, Y. J. I. Leuhoe² \\ 1,2Program Studi Teknik Informatika STIKOM Artha Buana Kupang \\ JIn. Samratulangi III No. 1 Walikota Kupang - NTT, 85111 \\ 1veraanwar08@gmail.com, 2siqma01@yahoo.com
}

\begin{abstract}
Integer programming is a mathematical model or part of linear programming that requires the result obtained to be a non-negative integer. In this case, researchers used an integer programming model to analyze the optimal production results of the "KURMA BABE" product. UD. Serba Karya is one of the SMEs in Kupang City that produces "BABE KURMA" with 2 models or variations, namely Ordinary Dates and Spoon Dates. The obstacle faced is that the business owner has not carried out proper production planning related to the use or combination of resources or production inputs so that the resulting product is not optimal. This of course will affect the profits obtained are not maximal. So with the integer programming model and the use of POM-QM For Windows V4 as an analytical tool, it is obtained that the optimal results are X1 (Ordinary Chair) $=4$ units, X3 (Ordinary Table) $=2$ units with $Z=18$ units (3 sets of "KURMA BABE"), with a profit of Rp. 1.050.000,- once production.
\end{abstract}

Keywords : Integer Programming, Optimal Production

\begin{abstract}
ABSTRAK
Integer programming menrupakan bentuk atau model matematis dari pemrograman linear yang mengharuskan atau mensyaratkan hasil yang diperoleh adalah bilangan bulat tak negatif. Dalam penelitian ini, peneliti menggunakan model integer programming untuk menganalisis hasil produksi yang optimal dari produk "KURMA BABE". UD. Serba Karya adalah salah satu UKM di Kota Kupang yang memproduksi "KURMA BABE" dengan 2 model atau variasi yaitu Kurma Biasa dan Kurma Spoon. Kendala yang dihadapi adalah pemilik usaha belum melakukan perencanaan produksi secara tepat terkait penggunaan atau kombinasi sumber daya atau input produksi sehingga produk yang dihasilakn belum optimal. Hal ini tentunya akan berpengaruh terhadap keuntungan yang diperoleh tidak maksimal. Sehingga dengan model integer programming dan penggunaan POM-QM For Windows V4 sebagai alat bantu analisis diperoleh bahwa hasil optimalnya adalah $\mathrm{X}_{1}$ (Kursi Biasa) $=4$ unit, $\mathrm{X}_{3}$ (Meja Biasa) $=2$ unit dengan $Z=18$ unit (3 set "KURMA BABE"), dengan keuntungannya sebesar Rp. 1.050.000,- sekali produksi.
\end{abstract}

Kata Kunci : Integer Programming, Produksi Optimal 


\section{PENDAHULUAN}

Dalam era revolusi industri 4.0, usaha industri rumahan (homeindustry) maupun industri berskala UKM memberi peluang besar bagi para wirausaha untuk lebih berinovasi dan berkompetisi terhadap produk yang dihasilkan guna memperoleh keuntungan yang maksimal. Menurut beberapa situs tentang "Peluang Usaha" maka usaha sampingan skala industri rumahan dan UMK menjadi pilihan bagi banyak wirausaha pemula karena beberapa faktor seperti modal yang kecil, tidak harus membutuhkan pengalaman yang besar dan dapat segera dimulai. Usaha ini pun memberikan peluang keuntungan yang cukup menjanjikan.

Adanya persaingan pasar yang terus meningkat menyebabkan pemilik usaha semakin dituntut untuk mampu menyusun strategi dengan baik agar tetap eksist dan unggul dalam usaha yang dijalankan. Dengan mempertimbangkan batasan-batasan sumber daya yang tersedia, pemilik usaha harus mampu membuat keputusan yang tepat sehingga sesuai dengan tujuan yang ingin dicapai. Salah satu keputusan penting yang harus diambil oleh pemiilik usaha adalah dalam hal perencanaan produksi, dimana produksi akan berkaitan dengan berkualitas dan tidaknya serta optimal dan tidaknya produk yang dihasilkan sehingga mencapai keuntungan yang diharapkan. Pemanfaatan sumber daya yang tepat sangat diperlukan dalam proses produksi, guna memperoleh hasil produksi yang optimal, yang pada akhirnya akan berpengaruh pada keuntungan yang diperoleh.

Provinsi Nusa Tenggara Timur merupakan salah satu provinsi di Indonesia yang memiliki jumlah UMKM yang cukup besar dan sedang berkembang saat ini. Menurut Kepala Seksi Fasilitas Usaha Koperasi dan UKM Dinas Koperasi, Tenaga Kerja dan Transmigrasi (Kopnakertrans) NTT, jumlah usaha mikro, kecil dan menengah (UMKM) yang tersebar di 22 kabupaten/kota sebanyak 104.157 unit. UMKM tersebut bergerak di berbagai bidang usaha yaitu dari usaha kuliner, barangbarang bekas, kosmetik, perabot rumah tangga sampai pada pariwisata, dan lain-lain. Salah satu bentuk usaha UMK yang sedang viral saat ini dan banyak diminati masyarakat NTT termasuk masyarakat Kota Kupang adalah usaha pembuatan kursi meja dari ban bekas "KURMA BABE", karena selain produknya tergolong unik dan antik, harganya pun terjangkau dan dapat meningkatan pendapatan pemilik usaha.

UD. Serba Karya adalah salah satu UMK yang yang bergerak di bidang produksi "KURMA BABE" dengan hasil yang tidak kalah dari segi kualitas serta model dan harga jual yang bervariasi. Pemilik usaha berupaya agar kombinasi input yang dilakukan, dapat menghasilkan produk yang optimal dan berkualitas. Ketatnya persaingan pada usaha UMK yang memproduksi produk yang sejenis akan membuat UMK tersebut terpacu untuk semakin berinovasi dalam menciptakan produkproduk yang lebih menarik dan beragam serta selektif dalam kualitas produk yang diproduksi. Oleh karena itu, maka dalam menjalankan kegiatan produksi, pemilik usaha perlu melakukan suatu perencanaan produksi secara tepat. Hal ini berguna untuk mempertahankan eksistensi perusahaan dalam menghadapi persaingan pasar. 
Persoalan yang lazim dihadapi oleh pemilik usaha adalah bagaimana mengoptimalkan produk yang harus diproduksi agar diperoleh keuntungan maksimal. Optimisasi produksi ini tentunya berkaitan dengan kombinasi sumber daya atau input produksi secara tepat. Pemilik usaha harus mengetahui model yang menghubungkan antara masalah atau kendala dengan alternatif pemecahan sehingga sesuai dengan tujuan yang hendak dicapai. Berdasarkan hasil wawancara dengan pemilik usaha, diperoleh informasi bahwa produk yang dihasilkan sesuai pesanan dan lebih mempertimbangkan segi kualitas. Sedangkan jumlah input yang digunakan tidak melalui suatu perencanaan perhitungan yang pasti melainkan berdasarkan pengalaman tenaga kerja dalam produksi. Hal inilah yang menjadi kendala dalam produksi "KURMA BABE" yaitu bagaimana mengkombinasikan input-input produksi secara tepat sehingga memperoleh hasil produksi yang optimal dan memperoleh keuntungan yang maksimal ?. Agar kombinasi input-input produksi dapat menghasiilkan produk "KURMA BABE" yang optimal maka peneliti menggunakan metode perhitungan Integer Programming (Kevin dan Rosyidi, 2016). Integer Programming merupakan salah satu model program linear yang dapat digunakan dalam pemecahan masalah pengalokasian sumber-sumber yang terbatas secara optimal, dimana solusi variabel keputusannya harus merupakan bilangan bulat (Purba, Sari; Ahyaningsih, 2020). Dengan penggunaan Interger programming ini diharapkan hasil produksi yang diperoleh menjadi optimal keuntungan yang diperoleh dapat maksimal.

\section{METODE PENELITIAN}

1. Memulai studi literatur.

2. Pengumpulan data menggunakan metode observasi dan wawancara.

3. Tabulasi data ke bentuk tabel.

4. Mem-formulasikan data ke bentuk matematika.

5. Analisa menggunakan POM-QM.

6. Menentukan hasil optimal dengan metode Linear programming dan Integer programming.

7. Selesai.

\section{HASIL DAN PEMBAHASAN}

\subsection{Hasil}

Data-data yang diperoleh dari UD. Serba Karya kemudian ditabulasi dalam bentuk Tabel 1.

Tabel 1 : Hasil Tabulasi Data

\begin{tabular}{|l|c|c|l|l|l|l|}
\hline \multirow{2}{*}{$\begin{array}{c}\text { Bahan Baku } \\
\text { Produksi }\end{array}$} & \multicolumn{4}{|c|}{ Jenis "KURMA" } & $\begin{array}{c}\text { Jumlah } \\
\text { Persediaan }\end{array}$ & Satuan \\
\cline { 2 - 7 } & $\begin{array}{c}\text { Kursi } \\
\text { Biasa }\end{array}$ & $\begin{array}{c}\text { Kursi } \\
\text { Spoon }\end{array}$ & $\begin{array}{l}\text { Meja } \\
\text { Biasa }\end{array}$ & $\begin{array}{c}\text { Meja } \\
\text { Kaca }\end{array}$ & & \\
\hline Ban Bekas & 10 & 10 & 5 & 5 & 500 & Pcs \\
\hline
\end{tabular}




\begin{tabular}{|l|c|c|c|c|c|c|}
\hline Paku & 700 & 700 & 300 & 300 & 3000 & Gram \\
\hline Spoon & 0 & 5 & 0 & 0 & 10 & Meter \\
\hline Kain & 0 & 5 & 0 & 0 & 10 & Meter \\
\hline Kaca & 0 & 0 & 0 & 2 & 2 & Meter \\
\hline Cat & 2000 & 2000 & 1000 & 1000 & 30000 & Gram \\
\hline Jumlah Produksi & 4 & 4 & 1 & 1 & & \\
\hline
\end{tabular}

Sumber : Data olahan UD. Serba Karya Kupang 2021

Tabel 2 : Harga Jual dan Keuntungan

\begin{tabular}{|l|l|l|l|}
\hline \multicolumn{1}{|c|}{ Jenis Produk } & \multicolumn{1}{c|}{ Quantity } & \multicolumn{1}{c|}{ Harga Jual } & \multicolumn{1}{c|}{ Keuntungan } \\
\hline Kurma Biasa & 1 Set (4 Kursi 1 Meja) & Rp. 1.300.000,- & Rp. 350.000,- \\
\hline Kurma Spoon & 1 Set (4 Kursi 1 Meja) & Rp. 1.500.000,- & Rp. 500.000,- \\
\hline
\end{tabular}

Sumber : Data olahan UD. Serba Karya Kupang 2021

Bentuk formulasi matematis dari pengunaan Input-input produksi dirumuskan menggunakan sistem linear programming sebagai berikut :

1. Variabel Keputusan.

Dari studi kasus di atas menunjukkan bahwa UD. Serba Karya memproduksi 4 jenis produk yaitu :

$\mathrm{X}_{1}=\sum$ produk kursi biasa

$\mathrm{X}_{2}=\sum$ produk kursi spoon

$\mathrm{X}_{3}=\sum$ produk meja biasa

$\mathrm{X}_{4}=\sum$ produk meja kaca

2. Fungsi Tujuan.

Yang menjadi tujuan pemilik usaha adalah produksi optimal. Oleh karena itu, fungsi tujuan dirumuskan :

$$
Z=4 X_{1}+4 X_{2}+X_{3}+X_{4}
$$

3. Fungsi Kendala.

Yang menjadi kendala atau batasan masalah dalam studi kasus ini adalah sumber daya atau input yang digunakan dalam produksi 'KURMA BABE". Input - input atau sumber daya tersebut, kemudian dirumuskan secara matematis sebagai berikut :

$$
\begin{aligned}
& 10 X_{1}+14 X_{2}+5 X_{3}+7 X_{4} \leq 500 \\
& 500 X_{1}+600 X_{2}+300 X_{3}+400 X_{4} \leq 3000 \\
& 4 X_{2} \leq 10 \\
& 4 X_{2} \leq 10 \\
& 1,5 X_{4} \leq 2 \\
& 1500 X_{1}+1500 X_{2}+500 X_{3}+500 X_{4} \leq 7000
\end{aligned}
$$

Dengan syarat : $X_{1}, X_{2}, X_{3}, X_{4} \geq 0$, integer 
Guna mempermudah perhitungan, peneliti menggunakan aplikasi POM-QM for Windows V4 sebagai alat bantu analisis data. Setelah aplikasi POM-QM for Windows V4 dijalankan, maka formulasi matematis di atas dimasukkan ke aplikasi dengan memilih module integer and mix integer programming. Tampilan setelah data-data dimasukkan akan terlihat seperti Gambar 1.

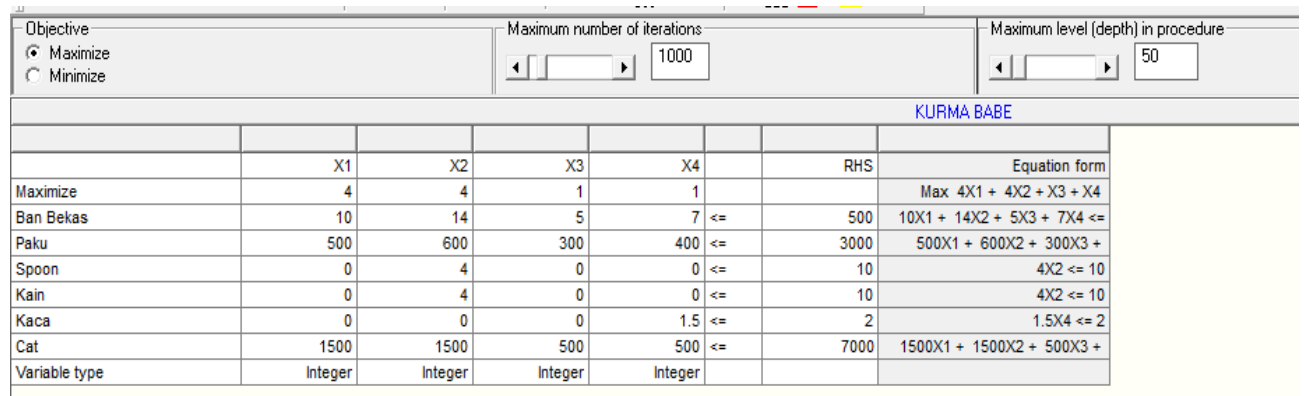

\section{Gambar 1 : Tabel Data POM-QM V4}

Data-data tersebut kemudian dianalisis dengan button "solve" sehingga diperoleh hasil yang ditunjukkan pada Gambar 2.

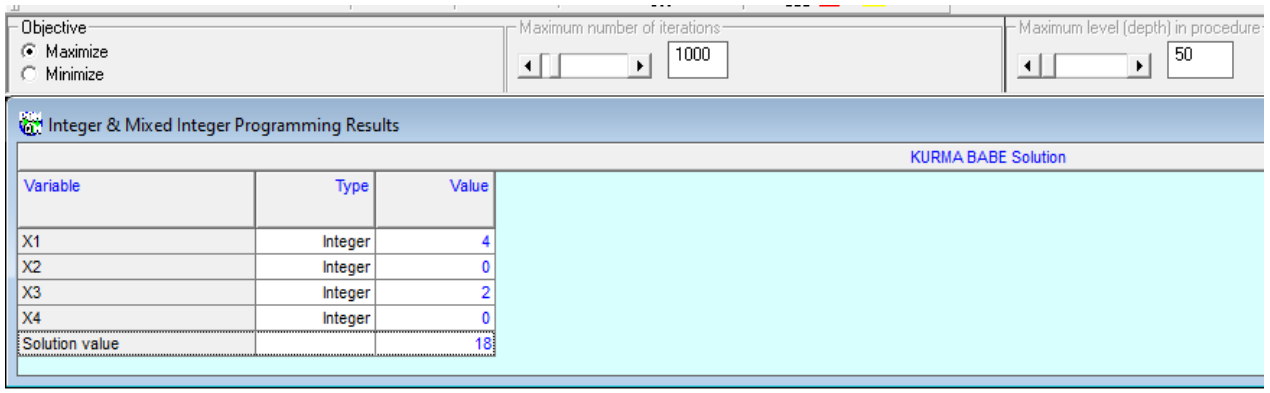

Gambar 2 : Integer \& Mix Integer Progamming Result

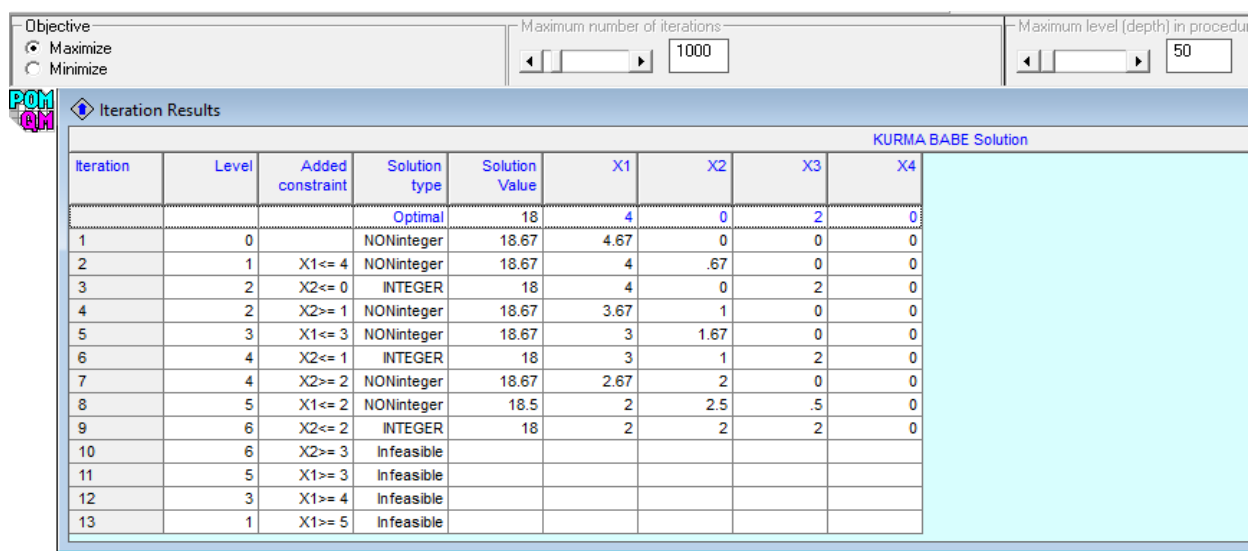

Gambar 3 : Iteration Result 


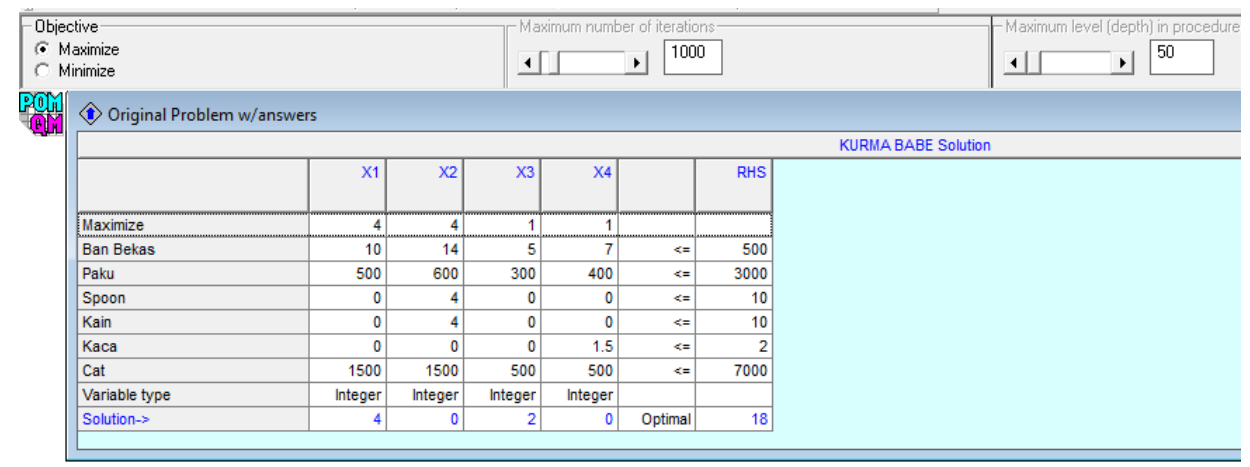

Gambar 4 : Original Problem W/Answears

\subsection{Pembahasan}

Berdasarkan hasil analisis pada Gambar 2. Integer \& Mix Integer Programming, diperoleh informasi bahwa produksi "KURMA BABE" yang optimal adalah $\mathrm{X}_{1}$ (Kursi Biasa) $=$ 4 unit, $X_{3}($ Meja Biasa) $=2$ unit dengan $Z=18$ unit ( 3 set "KURMA BABE"), sehingga keuntungan yang diperoleh adalah Rp. $350.000 \times 3$ set $=$ Rp. 1.050.000,- Jika dibandingkan dengan jumlah produksi saat ini maka keuntungan yang diperoleh pengusaha hanya sebesar Rp. 850.000,-. Hasil perhitungan matematis ini menunjukkan bahwa kombinasi input yang dilakukan pengusaha saat ini belumlah optimal sehingga berpengaruh terhadap jumlah produksi dan keuntungan yang diperoleh.

Pada Gambar 3. Iteration Result, menunjukkan bahwa dari iterasi pertama sampai keenam, dimana kombinasi input atau sumber daya yang menghasilkan jumlah produksi dengan nilai integer ada pada dua iterasi yaitu Iterasi kedua dimana jika $X_{2} \leq 0$, maka $X_{1}=4$, $X_{3}=2$ dan $Z=18$ dan Iterasi keenam dimana jika $X_{2} \leq 2$, maka $X_{1}=2, X_{2}=2, X_{3}=2$ dan $Z=$ 18. Dari kedua iterasi tersebut pastinya pengusaha akan memilih iterasi kedua dikarenakan penjualan "KURMA BABE" yang dilakukan dalam bentuk set atau paket (Kursi dan Meja). Pengusaha akan memilih iterasi keenam apabila melakukan penjualan secara eceran atau terpisah.

Persaingan pasar yang semakin ketat, dimana muncul produk-produk sejenis dengan kualitas dan model yang bervariasi, maka pengusaha dituntut untuk lebih berinovasi terhadap produk di dihasilkan sehingga dapat bersaing dengan produk lain, misalnya dengan memproduksi "KURMA BABE" berbentuk DONAT atau SOPA. Guna menghasilkan produkproduk tersebut, pengusaha harus tetap berorientasi pada penggunaan sumber daya produksi (input produksi) secara tepat, kualitas produk yang terjamin dan juga segmentasi pasar untuk meraih peluang pasar guna memperoleh keuntungan maksimal. 


\section{KESIMPULAN}

Aplikasi POM-QM For Windows V4 merupakan salat satu alat bantu analisis data dalam menghitung kombinasi penggunaan input atau sumber daya produksi yang mengharuskan hasil produksi dalam jumlah yang integer atau bilangan bulat (Interger Programming). Hasil analisis yang diperoleh dapat direkomendasikan kepada pemilik usaha atau pengusaha "KURMA BABE" UD. Serba Karya agar mengkombinasikan sumber daya atau input produksi yang dimiliki dengan tepat sehingga menghasilkan produk yang optimal dan nantinya akan meningkatkan keuntungan yang diperoleh. Hasil analisis POM-QM For Windows V4 untuk permasalahan produksi "KURMA BABE" UD. Serba Karya adalah $\mathrm{X}_{1}$ (Kursi Biasa) $=4$ unit, $\mathrm{X}_{3}$ (Meja Biasa) $=2$ unit dengan $\mathrm{Z}=18$ unit ( 3 set "KURMA BABE").

\section{DAFTAR PUSTAKA}

[1]. Kevin, Rosyidi, Optimasi Produksi Pia Cake Menggunakan Metode Integer Programming Di Ukm Xyz Desa Waru Rejo Gempol Pasuruan, Journal Knowledge Industrial Engineering (JKIE), 2016, pp. 23-32. doi: P-ISSN: 2460-0113 I E-ISSN: 2541-4461.

[2]. Purba, Sari; Ahyaningsih, F., Integer Programming Dengan Metode Branch And Bound Dalam Optimasi Jumlah Produksi Setiap Jenis Roti Pada PT. Arma Anugerah Abadi, KARISMATIKA, 6 no. 3, 2020, pp. 20-29. doi: p-ISSN : 2443 - 0366, e-ISSN : 2528 -0279 . 